\title{
PIOTR WINCZEWSKI
}

Uniwersytet Jana Kochanowskiego w Kielcach

\section{Wybrane uwarunkowania biografii rodzin osób niepełnosprawnych}

\begin{abstract}
Winczewski Piotr, Selected factors determining the family biographies of disabled people [Wybrane uwarunkowania biografii rodzin osób niepełnosprawnych]. Interdyscyplinarne Konteksty Pedagogiki Specjalnej, nr 2, Poznań 2013. Pp. 93-114. Adam Mickiewicz University Press. ISBN 978-83-232-2594-2. ISSN 2300-391X.

This article presents an account of research based on individual in-depth interviews. It emphasizes the aspects of the functioning of people with impairments which are difficult to capture by carrying out quantitative analysis. This paper is aimed to describe selected factors that determine the activity of disabled people, in particular those which could be used in further, more precise studies of disability.
\end{abstract}

KEY WORDS: disability, functioning of disabled people, biographies of people with disabilities

\section{Cel eksploracji}

Relacja terapeuta-pacjent ma charakter swoistego sprzężenia zwrotnego. Tak pedagog specjalny wnosi zmianę $\mathrm{w}$ funkcjonowanie wychowanka, jak i dopiero kontakt z podopiecznym kształtuje jego praktyczne kompetencje zawodowe. To właśnie z powodu powyższej zależności tak duże znaczenie $\mathrm{w}$ kształceniu przyszłych terapeutów przypisuje się praktykom; to dlatego wraz z wydłużającym się stażem pracy ich realne umiejętności pomnażają się. Jak się wydaje, proces wdrażania przyszłych specjalistów do zawodu może 
mieć także postać przybliżania im jego newralgicznych aspektów. Dzięki temu przyszli terapeuci są niejako wstępnie przygotowani na potencjalne bogactwo stojących przed nimi wyzwań.

Poniżej przedstawiono wybrane uwarunkowania biografii osób niepełnosprawnych i ich rodzin. Celem eksploracji jest zewidencjonowanie tych aspektów funkcjonowania osób niepełnosprawnych i ich rodzin, które relatywnie rzadko poddawane są analizom empirycznym.

Opisane przykłady odzwierciedlają rzeczywiste losy realnych osób.

\section{Materiał badawczy}

Prezentowany materiał gromadzono $\mathrm{w}$ trakcie trzech tysięcy spotkań z osobami niepełnosprawnymi o znacznych ograniczeniach lokomocyjnych i ich rodzinami. Badania prowadzono w każdym z szesnastu województw. Dobór próby miał charakter losowy. Przeważały w niej osoby po urazach rdzenia kręgowego, ze stwardnieniem rozsianym, mózgowym porażeniem dziecięcym oraz przepukliną oponowo-rdzeniową. Pacjentów typowali lekarze rodzinni oraz lekarze specjaliści neurologii i rehabilitacji w trakcie procedur medycznych. Pozyskiwanie danych trwało sześć lat.

Poniżej przedstawiono dwadzieścia pięć syntetycznych charakterystyk wybranych uwarunkowań funkcjonowania osób niepełnosprawnych w środowisku rodzinnym, rówieśniczym; w kilku przypadkach zrelacjonowano je nie wprost, ukazując okoliczności wykonywania świadczeń medycznych na rzecz osób niepełnosprawnych w zakładach opieki zdrowotnej.

\section{Metoda}

Prezentowane dane pozyskano w trakcie pogłębionych wywiadów określanych mianem głębinowych. Wywiady były nakierowane na ewidencjonowanie ograniczeń lokomocyjnych i komunikacyj- 
nych pacjentów ${ }^{1} . \mathrm{W}$ ich rezultacie zainicjowano oraz zrealizowano stosowane procedury medyczne i przezwyciężające bariery architektoniczne $\mathrm{z}$ wykorzystaniem środków resortu ochrony zdrowia, pomocy społecznej, PFRON, a także z celowych dotacji fundacji działających na rzecz osób niepełnosprawnych.

Opisana procedura niosła z sobą swoistą wartość dodaną. Było nią wyłonienie czynników relatywnie drugorzędnych dla świadczeń medycznych, które równocześnie wydają się wartościowe poznawczo dla badaczy wywodzących się ze świata nauk społecznych. W trakcie wywiadów, w uzupełnieniu procedur medycznych, stawiano pytania badawcze o wyznaczniki funkcjonowania osób niepełnosprawnych i ich rodzin. Równocześnie ewidencjonowano okoliczności funkcjonowania osób niepełnosprawnych, w które zaangażowane były osoby trzecie, w tym pracownicy ośrodków terapeutycznych.

W tej perspektywie metodę zbierania danych zaklasyfikować można jako skoncentrowany na problemie narracyjny jakościowy wywiad indywidualny $\mathrm{z}$ równoczesnym rejestrowaniem kontek$s^{2}{ }^{2}$. Pierwsza część badań (rejestrowanie ograniczeń lokomocyjnych i komunikacyjnych) miała charakter standaryzowanego wywiadu jawnego, a druga (wyznaczniki funkcjonowania rodzin) była wywiadem ukrytym niestandaryzowanym (swobodnym) ${ }^{3}$.

W niniejszym wystąpieniu zrelacjonowano pozamedyczne aspekty przeprowadzonych diagnoz. Mają one postać przedstawionych syntetycznie studiów przypadków ${ }^{4}$ oraz opisów okoliczności funk-

${ }^{1}$ M. Łobocki, Metody i techniki badań pedagogicznych, Impuls, Kraków 2005 (1984), s. 273 i nast.; por.: J. Miller, Care planning and the helping process, s. 253-295, [w:] J. Miller (red.), Care in Practice for Higher Still, Hodder Arnold, London 2005.

2 K. Rubacha, Metodologia badań nad edukacja, Wyd. Akademickie i Profesjonalne, Warszawa 2008, s. 129-151; por.: P. Baker, Interview, s. 226-235, [w:] D. Cormack (red.), The Research Process in Nurising, Blackwell Science, Oxford 1996.

3 A.W. Maszke, Metodologiczne podstawy badań pedagogicznych, Uniwersytet Rzeszowski, Rzeszów 2003, 154-163; por.: P. McNeill, Research Methods, Tavistock Publications, London 1986, s. 21.

${ }^{4}$ K. Rubacha, dz. cyt., s. 329 i nast. 
cjonowania osób niepełnosprawnych. Ten rodzaj sprawozdania z badań z pogranicza nauk społecznych i medycyny nazywa się czasem relacją $z$ badań 'metodą kliniczną' ${ }^{5}$.

Każdy z opisów podsumowano syntetycznym wnioskiem jednostkowym, dlatego cały materiał zamknięto nie wnioskami, ale podsumowaniem i konkluzją. Tym samym uwzględniono istotne czynniki metodologii deskrypcji fenomenologicznej wyeksponowane przez Krystynę Ablewicz ${ }^{6}$.

\section{Prezentacja wyników}

Poniżej przedstawiono dwadzieścia pięć opisów uwypuklających funkcjonowanie rodzin i najbliższych środowisk społecznych osób niepełnosprawnych. Relacji celowo nadano postać narracyjną, by pełniej oddać jakościowy charakter badań i wniosków. W związ$\mathrm{ku} \mathrm{z}$ tym pewne fragmenty wystąpienia konsekwentnie opisano $w$ pierwszej osobie liczby pojedynczej.

Ze względów redakcyjnych relację ograniczono do syntetycznego przedstawienia wybranych, istotnych poznawczo aspektów. Prezentowane relacje mające postać opisów przypadków uporządkowano alfabetycznie według kryterium słów kluczowych dla narracji.

\section{A jak Artystka}

Liczne osoby malujące ustami i nogami angażują się w tę formę aktywności amatorskiej po urazach rdzenia kręgowego czy amputacjach. Ta pacjentka była artystką z wykształcenia; doznała urazu rdzenia kręgowego tuż po studiach. Była magistrem sztuki, artystką-plastykiem.

${ }^{5}$ M. Łobocki, Wprowadzenie do metodologii badań pedagogicznych, Impuls, Kraków 2004 (1984), s. 263 i nast.

${ }^{6} \mathrm{~K}$. Ablewicz, Miejsce badań fenomenologicznych w poznawaniu sytuacji wychowawczych, s. 181-187, [w:] D. Kubinowski, M. Nowak (red.), Metodologia pedagogiki zorientowanej humanistycznie, Polskie Towarzystwo Pedagogiczne, Impuls, Kraków 2006. 
Wypadek nie przeszkodził jej w realizacji planów życiowych. Jej dom żywo przypominał pracownie innych artystów-plastyków. Gotowe prace oczekiwały na klientów. Pacjentka ukończyła studia blisko czterdzieści lat wcześniej. Niezmiennie przez ten czas utrzymywała się ze sprzedaży obrazów.

Niepełnosprawna odmówiła udziału $\mathrm{w}$ procedurach medycznych. Twierdziła, że tak wiele lat po urazie nie potrzebuje już nic zmieniać w swym życiu. Malarka w pełni zaadaptowała się do niepełnosprawności, $\mathrm{w}$ istocie rzeczy nie zmieniając zasadniczego planu życiowego sprzed urazu: wykonywała zawód wyuczony, z powodzeniem utrzymując się $\mathrm{z}$ niego. Wyuczony zawód stał się dla niej czynnikiem integrującym $\mathrm{w}$ przeciwstawianiu się niepełnosprawności. Wymowne przy tym jest to, iż ta swoista 'rehabilitacja zawodowa' odbyła się po pierwsze $\mathrm{w}$ czasach, gdy dopiero nieśmiało o niej wspominano w literaturze przedmiotu, a po wtóre bez żadnego wsparcia instytucjonalnego ze strony ochrony zdrowia czy służb opieki społecznej.

\section{B jak Bliskość}

Ośrodek rehabilitacyjny dla dzieci niepełnosprawnych $w$ niewielkiej miejscowości. O atmosferze panującej w ośrodku chyba najpełniej świadczy to, że jako portiera zatrudniono $\mathrm{w}$ nim byłego wychowanka.

Mężczyzna, wskutek mózgowego porażenia dziecięcego, nie władał kończynami dolnymi od urodzenia. Nie przeszkodziło mu to jednak $w$ ukończeniu szkoły średniej. Porażenie kończyn dolnych, mimo wieloletniej rehabilitacji ruchowej, nie ustąpiło. Pacjent nadal poruszał się na wózku inwalidzkim. Zarazem jednak jego rehabilitacja społeczna okazała się skuteczna: uzyskał zatrudnienie i samodzielność życiową.

Mężczyzna z dumą podkreślał, iż dla obecnych pacjentów ośrodka jest swoistym uosobieniem sukcesu życiowego odniesionego mimo niepełnosprawności ruchowej. Znalazł wszakże pracę, co w niewielkiej miejscowości bywa niełatwe nawet dla osób pełnosprawnych. W tym przypadku funkcjonowanie ośrodka rehabilita- 
cyjnego nabierało swoiście symbolicznej wymowy. Oto na rzecz osób niepełnosprawnych działał nie tylko personel pełnosprawnych terapeutów.

Opisane okoliczności dostarczyły wychowankom ośrodka pozytywnego przykładu skuteczności rehabilitacji i tym samym były czynnikiem motywującym do wysiłków. Pogląd taki wyrażał nie tylko opisany mężczyzna, ale także personel placówki.

Być może w opisanym przypadku pozytywne skutki rehabilitacji były tak czytelne, ponieważ rozgrywała się ona $\mathrm{w}$ niewielkiej miejscowości. Tu zapewne pracownicy ośrodka w szczególny sposób czuli się odpowiedzialni za skutki swej pracy. W dużym mieście, $\mathrm{z}$ powodu mnogości instytucji zaangażowanych $\mathrm{w}$ procedurę rehabilitacyjną, być może odpowiedzialność za jej skutki byłaby rozmyta, a tym samym determinacja zaangażowanych w nią byłaby mniejsza.

\section{C jak Córka}

Dziewczynka z mózgowym porażeniem dziecięcym, córka jednej z niegdyś szczególnie prominentnych osób. Jej ojciec, w obliczu niepełnosprawności córki, był tak samo bezradny, jak inni rodzice niepełnosprawnych dzieci. Jego pytania, dociekania i zaradność realnie nie odbiegały od typowych dla innych rodziców. Jego eksponowana pozycja nie zapewniała mu żadnych preferencji w zmaganiu się z codziennymi wyzwaniami.

Rodzina żyła skromnie, co stało w wyraźnym kontraście z jej niegdysiejszą pozycją finansową. Ojciec z dumą podkreślał, iż całe zasoby materialne rodzina inwestowała $w$ rehabilitację córki; w rozmowie w cztery oczy podkreślał, że nie żałuje, iż zrezygnował z eksponowanego, intratnego stanowiska publicznego. We wołanej ocenie, angażując się w dochodową pracę, mniej mógłby fizycznie pomagać córce. Mężczyzna zauważył, iż efektywność jego pracy z córką jest wyższa niż uzyskiwana przez osoby trzecie.

Opisywana rodzina zreorientowała swe cele $\mathrm{z}$ materialnych na opiekuńcze. Wedle deklaracji jej przedstawiciela nie pociągnęło to za sobą subiektywnego poczucia straty u domowników. 


\section{D jak Dogoterapia}

Skuteczności zooterapii nie przebadano jeszcze empirycznie tak dogłębnie, jak na przykład licznych metod kinezyterapeutycznych. $\mathrm{Z}$ tego powodu daje się zaobserwować pewnego rodzaju dystans wobec tej formy zajęć.

Rodzice chłopca z mózgowym porażeniem dziecięcym poprosili o zdiagnozowanie jego aktywności ruchowej w grupie rówieśniczej w ośrodku terapeutycznym. Tego dnia dzieci miały odbyć kolejny seans dogoterapii. Niestety, ze względu na mroźną zimę przyjazd opiekuna z psami znacznie opóźniał się.

Smutek odmalowujący się na twarzach dzieci długo oczekujących na spotkanie z psami trudno wysłowić. Takie emocje nie podlegają kategoryzacji badań ilościowych. W badaniach jakościowych też trudno je oddać. Dzieci w niepewności czekały godzinę na opóźniający się przyjazd zwierząt. Pośród oczekujących byli pacjenci $z$ autyzmem, mózgowym porażeniem dziecięcym, upośledzeniem umysłowym. Liczne dzieci nie znały pojęcia czasu, z wieloma z nich nie dało się nawiązać i utrzymać kontaktu wzrokowego; widać jednak było, że dobrze znają pojęcie spotkania z psami.

Ten błysk w oczach, uśmiech rozpromieniające się twarze, gwałtowne formy ekspresji ruchem, głosem, wyrazem twarzy, które pojawiły się po przyjeździe psów, trudno opisać. Dzieci z biernych, apatycznych, smutnych, zamkniętych w sobie, w jedną chwilę stały się radosne.

Trudno na podstawie jednostkowej obserwacji postulować otwarcie procesu rehabilitacyjnego na nowe formy terapii. Zarazem jednak w kontekście poczynionych obserwacji trudno utrzymać sceptycyzm wobec nich.

E jak E-mail

W sformalizowanych kontaktach terapeuta i pacjent w naturalny sposób starają się dochować wymogów etykiety, form grzecznościowych. Jako element dobrego tonu traktuje się zachowanie tych reguł także w komunikacji elektronicznej. Wydaje się to jeszcze 
bardziej istotne dla osób, które na co dzień władają językiem w piśmie, wykonując swój zawód.

Aktywna zawodowo dziennikarka, która uległa wysokiemu urazowi rdzenia kręgowego w okolicy szyjnej, podając swój adres poczty elektronicznej zawczasu zastrzegła, że przeprasza za formę listów. Ze względu na ograniczenia sprawności dłoni nie była w stanie swobodnie stosować wielkich liter i znaków diakrytycznych. Choć wstawianie ich do tekstu jest możliwe przy użyciu jednej dłoni, to jednak jest to relatywnie długotrwałe. Dlatego dziennikarka otwarcie prosiła o wyrozumiałość, podkreślając, że wolałaby zainwestować oszczędzony czas $w$ inne działania.

Ten przypadek jest sygnałem o potencjalnej możliwości występowania $\mathrm{w}$ procesie rehabilitacji stanów analogicznych do nazywanych w innych dziedzinach "przesterowaniem” układu. Otóż wskutek wysokich kompetencji językowych niepełnosprawna dziennikarka odczuwała dyskomfort $\mathrm{z}$ powodu formalnej strony swych listów elektronicznych. Dla innych osób niepełnosprawnych napisanie takiego listu po tak wysokim urazie rdzenia kręgowego byłoby sukcesem samym w sobie.

\section{F jak Fabryka}

Nastolatka była przygotowywana przez rodzinę do przejęcia $\mathrm{w}$ przyszłości zarządzania częścią rodzinnego interesu - jednego z potentatów krajowego rynku. Była wyróżniającą się uczennicą szkoły średniej. Rodzice byli dumni z tego, jak bardzo była zdeterminowana do studiowania $\mathrm{w}$ renomowanej uczelni. Na kilka tygodni przed maturą uległa wypadkowi komunikacyjnemu. Jego skutki były rozliczne. Stała się osobą głęboko niepełnosprawną. Wiele wskazywało na to, że nie będzie w stanie wypełnić planów rodziny.

Mimo znacznych ograniczeń ruchowych kilka lat później ukończyła studia, potem kolejne. Mimo nieodwracalnych skutków wypadku pracuje $\mathrm{w}$ firmie rodzinnej.

Jej postawę życiową i determinację wielokrotnie przypominały lokalne media. Jest przykładem hartu ducha i sił witalnych. Jej rodzina podkreśla, że niemałą rolę $\mathrm{w}$ skuteczności rehabilitacji miały 
wysokie zasoby materialne; pacjentka odbywała intensywną, codzienną rehabilitację $\mathrm{w}$ domu finansowaną przez rodzinę.

To wniosek wręcz trywialny, zarazem jednak nie należy powstrzymywać się przed jego wyartykułowaniem, bo bywa punktem krytycznym w licznych przypadkach: zasobność materialna rodziny niejednokrotnie warunkuje skuteczność rehabilitacji.

\section{G jak Godność}

O tym trudno napisać bez wzbudzania kontrowersji. Zarazem jednak nie sposób przemilczeć tę obserwację, bo niełatwo znaleźć podobną $\mathrm{w}$ innych relacjach $\mathrm{z}$ badań.

Otóż w domach pomocy społecznej na południu Polski można spotkać relatywnie więcej osób niepełnosprawnych umysłowo i chorych psychicznie niż w innych częściach kraju. Ten wniosek wyartykułował ojciec nastolatki z mózgowym porażeniem dziecięcym. Stwierdził on, że góralom "godność nie pozwala, by przestawać opiekować się niepełnosprawnym członkiem rodziny". Według relacji ojca pacjentki posłanie domownika do domu pomocy społecznej traktują oni jako ostateczność, jako osobistą porażkę.

Trudno ocenić, czy ten opis odzwierciedla stan rzeczywisty. Pobieżna lustracja kilku domów pomocy społecznej w tej części kraju zdaje się potwierdzać jego słowa. Oczywiście dla zgeneralizowania tej obserwacji konieczne są pogłębione badania.

Na powyższym przykładzie można wnioskować, że być może pewne aspekty działań opiekuńczych rodzin warunkowane są nie tylko wspólnymi dla populacji całego kraju normami społecznymi, ale także regionalnymi tradycjami i uwarunkowaniami kulturowymi. Oczywiście domniemanie to jest prawomocne o tyle tylko, o ile odrębne badania potwierdzą zacytowaną intuicyjną ocenę stanu rzeczy.

\section{H jak Honor}

Nastolatkowie łatwo ulegają emocjom i presji grupy. W ostatnim dniu roku szkolnego grono absolwentów wybrało się nad zbiornik wodny. Woda była zimna, nie było zdecydowanych na 
pływanie. Chłopcy zaczęli prześcigać się w docinkach ubliżających mającym obawy przed kąpielą. W końcu jeden $z$ nich nie wytrzymał presji. Skoczył do zbyt płytkiej wody. Doznał urazu rdzenia kręgowego w okolicy szyjnej kręgosłupa. Broniąc swego honoru w obliczu docinków rówieśników, stał się niepełnosprawnym.

Był on pierwszą osobą, z którą wcześniej pracowałem jako pełnosprawną, a potem jako pacjentem. Pierwszy raz spotkałem się z nim, gdy był kilkulatkiem. Po wielu latach, które minęły od jego wczesnego dzieciństwa, już mnie nie pamiętał. Chyba dzięki temu było nam lżej pracować z sobą. Młodzieniec w dojrzały sposób relacjonował wydarzenia bezpośrednio poprzedzające wypadek sprzed lat.

Wniosek: czynnikiem sprawczym prowadzącym do niepełnosprawności może być presja grupy, której szczególnie łatwo ulegają osoby nastoletnie. Dzieciom z jednej strony trudno oszacować stopień niebezpieczeństwa $\mathrm{w}$ ryzykownych sytuacjach, ale $\mathrm{z}$ drugiej wyzwaniem jest ukazanie rówieśnikom siebie jako osoby odważnej. Jak się wydaje, z tego powodu trudno zaprojektować w pełni skuteczne działania profilaktyczne chroniące nastolatków przed ryzykownymi zachowaniami prowadzącymi ich czasem do niepełnosprawności.

\section{I jak Instruktorzy}

Pierwszy trening osób uczących się aktywnego pokonywania barier architektonicznych na wózkach inwalidzkich. Każda z tych osób ledwie kilka miesięcy wcześniej uległa urazowi rdzenia kręgowego. Ledwie co potrafią poruszać się na wózkach; z zapartym tchem śledzą popisy instruktorów prowadzących zajęcia. Ci przejeżdżają z rozpędu kilkunastocentymetrowe stopnie. Pokazują, jak podjechać pod kilkustopniowe schody, jak z nich zjechać. Prezentują także, jak bezpiecznie upaść z wózka i jak potem samodzielnie na nim usiąść. Jakże są podobni do młodych ludzi, którzy popisują się, skacząc na deskorolkach i rowerach BMX przez przeszkody.

Instruktorzy to także osoby po urazach rdzenia kręgowego. Sami kilka lat wcześniej pojawili się na zajęciach w roli obserwatorów. Niektórzy z dzisiejszych obserwatorów za kilka lat będą instruktorami. Zapewne też będą prezentowali podobne wyczyny. 
Jak można zauważyć, skłonność do wyczynu, popisywania się nie ustaje $u$ osób niepełnosprawnych. I one, na podobieństwo swych rówieśników, prześcigają się $\mathrm{w}$ wypełnianiu coraz to nowych, ryzykownych wyzwan. $\mathrm{W}$ indywidualnych rozmowach instruktorzy podkreślali, iż $\mathrm{w}$ ich ocenie niepełnosprawność nie pozbawia prawa do ryzyka. $W$ ich ocenie niebezpieczne ewolucje dostarczając "adrenaliny", czynią ich osobiste doświadczenia życiowe bardziej autentycznymi.

\section{J jak Jabłka}

Masywny mężczyzna po urazie rdzenia kręgowego w okolicy piersiowej. $\mathrm{W}$ jego stawach biodrowych już $\mathrm{w}$ kilka miesięcy po urazie pojawiły się zwapnienia wydatnie ograniczające możliwość pionizacji. Mężczyzna nie mógł przyjmować pozycji siadu na wóz$\mathrm{ku}$. Zmiany okazały się nieodwracalne. Były one w pewnym stopniu skutkiem tego, że po powrocie ze szpitala niepełnosprawnym nikt nie mógł się zająć $\mathrm{w}$ domu. Zaniechano wówczas codziennych ćwiczeń zaleconych przez lekarza. Był zbiór owoców - główne źródło utrzymania osób prowadzących gospodarstwo rodzinne.

Pierwszy raz spotkaliśmy się w sadzie. Niepełnosprawny mężczyzna towarzyszył rodzinie pracującej przy kolejnych zbiorach owoców. Wpółsiedział na wózku z odchylanym podparciem pod plecy. Naszą rozmowę co kilka chwil przerywały zdania rzucane przez niepełnosprawnego $\mathrm{w}$ kierunku zrywających owoce. Widać było, że jest szczęśliwy.

Opisany przykład wskazuje, jak rodzina ściśle uzależniona od rytmu naturalnego gospodarowania staje przed dylematem wyboru pomiędzy doraźnym wsparciem osoby tracącej sprawność i długofalową dbałością o byt. Jak się wydaje, $\mathrm{w}$ takiej sytuacji nie ma możliwości dokonania wyboru $\mathrm{w}$ pełni korzystnego.

K jak Karty

Publicystyka ukuła określenie „wyścig szczurów” dla nazwania intensywnej rywalizacji o prestiżowe stanowisko, zmaksymalizowanie dochodów. Takie warunki niejednokrotnie marginalizują 
osoby niepełnosprawne. Trudno im bowiem rywalizować o stanowisko pracy z pełnosprawnymi konkurentami, gdyż niejednokrotnie potencjalni pracodawcy $\mathrm{z}$ trudem przezwyciężają stereotypy myślenia o osobach niepełnosprawnych.

W jednym z domów pomocy społecznej, w województwie mazowieckim, zastałem przy stole karcianym czterech dwudziestokilkulatków po urazach rdzenia kręgowego. Ich licznych rówieśników z bliźniaczymi dysfunkcjami znałem jako osoby aktywne zawodowo. W innych częściach kraju desperacko poszukiwaliby zatrudnienia; czasem by je znajdowali. Nie wiem, czy nie szukali go dlatego, że byli przeświadczeni, iż nie są w stanie go znaleźć. Być może uważali tak ich potencjalni pracodawcy.

Z powyższej sytuacji wypływają intrygujące pytania badawcze o zróżnicowanie recepcji niepełnosprawności przez potencjalnych pracodawców w różnych rejonach kraju oraz o aktywność zawodową osób z poszczególnymi rodzajami niepełnosprawności.

\section{L jak Los}

Z członkami tej rodziny spotkałem się w odstępie kilku dni. Najpierw rozmawiałem $z$ ojcem artykułującym głosem przepełnionym irytacją i złością na najmłodszego syna; ojciec narzekał na los uniemożliwiający mu przekazanie firmy w jego ręce. Najmłodszy syn urodził się, gdy pozostałe rodzeństwo już dorastało. Po kilku latach starsze rodzeństwo rozjechało się po świecie. $W$ tym czasie ojciec odniósł prawdziwy biznesowy sukces. Planował, iż najmłodszy syn pomoże mu w prowadzeniu rodzinnego przedsiębiorstwa o mocnej rynkowej pozycji. Tymczasem syn uległ wypadkowi w trakcie brawurowej jazdy samochodem.

Chłopca spotkałem w ośrodku rehabilitacyjnym dla osób niepełnosprawnych. Był w pełni zaadaptowany do niepełnosprawności; roześmiany bawił się $\mathrm{w}$ gronie nastoletnich rówieśników. Pierwszy raz rozmawialiśmy na chwilę przed dyskoteką, na którą się wybierał. I on z irytacją w głosie opowiadał o planach ojca. Nie zamierzał włączyć się w prowadzenie rodzinnej firmy; planował studia rozbieżne $\mathrm{z}$ profilem jej działalności. 
W ocenie ojca czynnikiem uniemożliwiającym przekazanie firmy synowi była jego niepełnosprawność. $W$ ocenie syna czynnikiem tym była jego własna niechęć do zaangażowania się $\mathrm{w}$ działalność gospodarczą ojca.

$\mathrm{Z}$ opisanej sytuacji wypływa wniosek, że i niepełnoletnie osoby niepełnosprawne niejednokrotnie znajdują $\mathrm{w}$ sobie wiele siły do aktywnego polemizowania z planami rodziców co do własnej przyszłości. Niepełnosprawność $\mathrm{w}$ opisanym przypadku nie pozbawiła chłopca pewności siebie i determinacji $\mathrm{w}$ próbach zupełnego usamodzielnienia się.

\section{Ł jak Łzy}

Wizytę u tego mężczyzny pamiętam szczególnie. Był chory na stwardnienie rozsiane. $\mathrm{W}$ jego przypadku choroba postępowała niepowtarzalnie szybko; poruszał się na wózku. Zapamiętałem go chyba tak szczególnie, dlatego że początkowo to nie ja nie miałem z nim pracować.

To ja wniosłem do pokoju plik kart pracy z pacjentami. Odruchowo, jak zwykle, połowę z nich wręczyłem koledze. Przez kilka chwil w milczeniu każdy $\mathrm{z}$ nas wczytywał się w syntetyczne informacje o osobach, z którymi mieliśmy pracować: imię, nazwisko, wiek, adres zamieszkania, schorzenie, ograniczenia lokomocyjne.

Po wstępnej lekturze kart pracy uniosłem wzrok, zerkając ku koledze. Trudno mi wyprzeć $\mathrm{z}$ pamięci widok jego twarzy. $\mathrm{Z}$ jego oczu płynęły łzy. Okazało się, że otrzymał kartę pracy opisującą jego kolegę z ławki szkolnej, z którym niegdyś wyczynowo trenował koszykówkę. Jego znajomy, którego zapamiętał jako jednego z najlepszych graczy drużyny juniorskiej, stał się osobą niepełnosprawną. Kolega poprosił mnie o zastępstwo, gdyż nie czuł się na siłach jechać do znajomego sprzed lat.

Z powyższej sytuacji wypływa wniosek o obiektywnie trudnym przygotowaniu się do pracy z osobami głęboko niepełnosprawnymi. Nawet przygotowani do tego terapeuci natrafiają na trudności emocjonalne. $\mathrm{W}$ tle pojawia się również pytanie o przygotowanie rodziny do poradzenia sobie $\mathrm{z}$ niezapowiedzianą niepełnosprawno- 
ścią któregoś z jej członków. Kompetencje terapeutów formuje się wszakże przez wiele lat studiów, praktyk zawodowych, kolejnych szczebli specjalizacji. Rodzina osoby niepełnosprawnej niejednokrotnie musi dojrzewać emocjonalnie do radzenia sobie $\mathrm{z}$ nową sytuacją przez pojedyncze dni.

\section{M jak Mistrzyni}

Maturzystka doznała urazu rdzenia kręgowego w okolicy szyjnej kręgosłupa w trakcie zabaw z koleżankami i kolegami na pływalni. Nieomal całkowicie utraciła władzę w dłoniach. Przed urazem trenowała koszykówkę, wcześniej próbowała swych sił także w wyczynowym pływaniu.

Maturę zdała rok później niż rówieśnicy. Rozpoczęła studia pierwszego stopnia, potem ukończyła kolejne. Pracuje zawodowo. W ramach obozów aktywnej rehabilitacji pływa, jeździ konno, lata na paralotni. Odwiedziła swoich byłych rehabilitantów obecnie pracujących w Kanadzie, Australii, Szwecji.

Czterokrotnie reprezentowała Polskę w Mistrzostwach Świata w jednej z dyscyplin sportu osób niepełnosprawnych. Hartem ducha i determinacją w dążeniu do celu mogłaby obdzielić licznych pełnosprawnych.

Opisany przykład nakazuje zapytać o granice hartu ducha osób o znacznej niepełnosprawności. Zdają się one czasem wykraczać poza te, które są typowe dla ich pełnosprawnych rówieśników. Choć brakuje narzędzi, które pozwalałyby uchwycić przemianę determinacji w dążeniu do realizacji celów życiowych sprzed urazu i po nim (trudno wszakże wychwycić w badaniach osoby, które ulegną wypadkom), to wyniki takich dociekań mogłyby być interesujące.

\section{N jak Nogi}

Kilkuletnia dziewczynka z przepukliną oponowo-rdzeniową. Kilka chwil rozmowy z nią pozwoliło zorientować się, że w każdym zespole klasowym należałaby do grona liderów; energiczna, o bogatych skojarzeniach, swobodnie werbalizująca obserwacje, dostrzegająca kontekstowe aspekty rozmowy. 
Dziewczynka odbywała lekcje $\mathrm{w}$ domu. Chętnie rysowała. W pracach plastycznych przedstawiała siebie zawsze bez nóg. Według relacji rodziców nie dbała o higienę kończyn dolnych. Oczekiwała bowiem, że nogi, o które nie będzie dbała, kiedyś „same jej odpadną". To w jej mniemaniu miało rozwiązać jej problemy lokomocyjne, bo niesprawne nogi stanowiły dla niej znaczne wyzwanie w trakcie przesiadania się z wózka na łóżko, fotel i tym podobnych czynnościach życia codziennego.

Postawa dziewczynki jawnie kontrastowała z jej błyskotliwością, wiedzą, bogatymi skojarzeniami. Rzadko kiedy u dziecka można zaobserwować „mechanizm wyparcia” w tak podręcznikowej postaci. Najmłodsi częściej zadają rodzicom i terapeutom pytanie o przyczynę swojej niepełnosprawności, z nadzieją oczekują odwrócenia procesów biologicznych.

\section{O jak Oko}

Podczas spotkania $\mathrm{z}$ tą nastolatką z mózgowym porażeniem dziecięcym terapeuta wręcz fizycznie doświadczył, jak silne są emocje osób niepełnosprawnych.

Dziewczyna $w$ trakcie rozemocjonowania doznawała silnej spastyczności. Podczas rozmowy, przysłuchując się scenariuszowi potencjalnej terapii, była tak uradowana, że napięcia mięśni jej kończyn górnych $w$ jednej chwili stały się nieprzewidywalne. Traf zrządził, że terapeuta pochylał się wtedy nad siedziskiem jej wózka. Nie dał rady uchylić się przed bolesnym uderzeniem w oko.

Potencjalne urazy personelu placówek ochrony zdrowia pracującego z osobami niepełnosprawnymi (asekurującego, przenoszącego, podtrzymującego) to aspekt relatywnie rzadko poddawany rozważaniom.

\section{P jak Pieczątki}

Niewielkie miasteczko na pograniczu trzech województw. Dorosły, niepełnosprawny syn pod opieką zaawansowanych wiekiem rodziców. W jego schorzeniu konieczne było stosowanie pielucho- 
majtek. Niewydolna ekonomicznie rodzina korzystała ze środków pomocy społecznej dofinansowujących ich zakup. Działo się tak od kilku lat. Ośrodek pomocy społecznej względnie rytmicznie i płynnie udzielał wsparcia. Nic nie zapowiadało zmiany procedur.

$\mathrm{W}$ tamtym roku środki rozdzielono jednak odmiennie. Do jesieni nie zapadła decyzja o skierowaniu środków do osób niepełnosprawnych, choć wpłynęły one już wiosną na konto samorządu. Decyzja administracyjna o wypłacie środków trafiła jednak do beneficjenta równo tydzień przed wyborami samorządowymi. Ostemplowało ją imiennymi pieczątkami pięć osób; każda startowała w nadchodzących wyborach. Na bliźniaczych decyzjach z minionych lat okazywanych przez rodzinę widniała za każdym razem tylko jedna pieczęć imienna.

Z powyższego stany rzeczy wypływa pytanie badawcze o pozamerytoryczne uwarunkowania pracy administracji publicznej działającej na rzecz osób niepełnosprawnych.

\section{R jak Respekt}

Niewielkie miasto w środku Polski. Mężczyzna zapewniał byt żonie i córce, pracując jako ochroniarz. Inwestował w swe kompetencje zawodowe, ćwicząc godzinami na siłowni. Jego postura budziła respekt. W gronie kolegów uchodził za najskuteczniej odstraszającego potencjalnych agresorów już samą sylwetką. Gdy stał się osobą niepełnosprawną, rodzina $\mathrm{z}$ nostalgią wspominała minioną sprawność mężczyzny.

W dniu wypadku miał scysję z kilkoma niedoszłymi klientami lokalu. Nie wpuścił ich do środka. Potraktowali to jak obrazę. Najprawdopodobniej czekali aż zakończy pracę; prawdopodobnie to oni pobili go, gdy wracał sam do domu. Doszło do wysokiego urazu rdzenia kręgowego oraz wstrząśnienia mózgu. Wskutek tego ostatniego nie zapamiętał napastników. Amnezja po wstrząśnieniu mózgu objęła też wcześniejszą scysję. Dowiedział się o niej z relacji świadków; każdy z nich jednak zasłaniał się niepamięcią, unikając wskazania sprawców zdarzenia. 
Kilka miesięcy po urazie mężczyzna nie był w stanie samodzielnie spożywać pokarmów; uniemożliwiało mu to spastyczne napięcie mięśni. Karmiła go żona, która, opiekując się mężem, nie była w stanie utrzymać zatrudnienia. Świadczeń od pracodawcy mężczyzny rodzina nie otrzymywała, ponieważ zatrudniano go na podstawie umów-zleceń.

Mężczyzna praktycznie stał się więźniem własnego pokoju. Rodzina mieszkała na piętrze, na które wiodły drewniane schody. Trudno byłoby sobie wyobrazić znoszenie po nich tak masywnego pacjenta.

Opisany przypadek inspiruje do postawienia pytania badawczego o przemiany statusu osób, które stają się niepełnosprawnymi, nie mając zabezpieczenia społecznego. Być może pogłębione ukierunkowane badania ukazałyby skalę problemu i byłyby czynnikiem inicjującym ewentualne zmiany prawa w tym zakresie.

\section{S jak Skoczkowie}

To była rozmowa z lekarzem prowadzącym bezpośrednio poprzedzająca spotkanie z pacjentem. Odbyła się w pokoju lekarskim szpitala zlokalizowanego pośrodku jednego z pojezierzy. Oddział przygotowywał się do pełnienia sobotnio-niedzielnego dyżuru, w czasie którego należało utrzymać gotowość do operowania ofiar wypadków, w tym niefortunnych „skoczków” do wody, którzy doznawali urazów rdzenia kręgowego w okolicy szyjnej kręgosłupa. W pokoju było kilku lekarzy.

W pewnej chwili, w trakcie rozmowy, wszyscy lekarze zwrócili głowy w stronę telewizora. Prezentowano akurat weekendową prognozę pogody; zapowiadano ulewy. Słuchający prognozy lekarze dosłownie popadli w euforię. Przy deszczowej pogodzie nikt nie skacze do wody, więc można było przewidywać spokojniejszy przebieg dyżuru.

Opisany obraz ukazuje, że prawdopodobnie można odnotować zależności statystyczne ukazujące związki pomiędzy klimatem (pogodą) i częstością występowania urazów określonego rodzaju. 


\section{T jak Terapeutka}

Po czwartym roku studiów medycznych jedna z wyróżniających się studentek doznała urazu rdzenia kręgowego w okolicy szyjnej. Władze uczelni nie wyraziły zgody, by kontynuowała studia medyczne. Nie odwiodło jej to jednak od zamiaru ukończenia studiów jako takich. Niepełnosprawna uzyskała tytuł zawodowy magistra psychologii $w$ innej uczelni. Jej pracę magisterską nagrodził minister.

Obecnie, mimo niepełnosprawności, pracuje jako psychoterapeutka z pacjentami onkologicznymi w jednej z klinik uczelni, której nie mogła ukończyć z powodu urazu rdzenia kręgowego. Jest matką trzyletniego chłopca.

Powyższy przykład ukazuje, że istotnym komponentem sukcesu życiowego osób niepełnosprawnych jest przebojowość, którą wykazywały się już przed urazem. Choć takie badania porównawcze wydawałyby się trudne do przeprowadzenia, to chciałoby się uzyskać wgląd w różnice indywidualnych biografii osób niepełnosprawnych, które przed urazami były operatywne oraz bierne.

\section{U jak Urzędnik}

$\mathrm{W}$ jednym z często odwiedzanych przez turystów miast pełnomocnikiem prezydenta do spraw osób niepełnosprawnych został człowiek poruszający się na wózku. Ten gest doceniły lokalne media oraz środowiska osób niepełnosprawnych.

Pełnomocnik zamierzał wywiązać się z powinności zarówno wobec zwierzchników, jak i społeczności osób niepełnosprawnych. Okazało się jednak, że miasto znacząco zredukowało środki przeznaczane na potrzeby osób niepełnosprawnych. Postawiło to niepełnosprawnego rzecznika $\mathrm{w}$ niełatwej sytuacji. Oto środowiska osób niepełnosprawnych zaczęły postrzegać go jako urzędnika jednego ze sprawców tego stanu rzeczy. Z goryczą wyrzucał sobie, że dał się skusić iluzją możliwości wpływania na zmiany. Choć niegdyś był liderem lokalnej społeczności osób niepełnosprawnych, poczuł się $\mathrm{z}$ niej wyobcowany. Ten stan jednak nie trwał długo; wkrótce doszło do przesilenia. 
W kuluarach okolicznościowego spotkania środowisk osób niepełnosprawnych ściszonym głosem, z tajemniczą miną, oznajmiał, że ma dla wszystkich niespodziankę. Powstrzymywał się jednak z jej ogłoszeniem do przybycia mediów. W świetle reflektorów, śledzony przez kamery telewizyjne, publicznie oznajmił prezydentowi miasta swe niezadowolenie.

Po publikacjach prasowych oświadczenia i wyemitowaniu materiału w telewizji przełożony zwolnił go z pracy.

Opisany przykład ukazuje próby instrumentalnego wpływania na wizerunek jednostek administracji lokalnej w oczach mieszkańców, w które wikłają się osoby niepełnosprawne.

W jak Wizytówka

Niejednokrotnie pisząc o niepełnosprawnych ruchowo dzieciach, zapomina się, że są to nadal beztroskie maluchy. Żartują, bawią się, są wesołe jak ich pełnosprawni rówieśnicy.

W czasie zajęć wspólnych dla grupy dzieci poruszających się na wózkach "aktywnych" (tzn. do tzw. aktywnej rehabilitacji) po raz pierwszy spotkałem się z kilkulatką. Rozmowę jednak musieliśmy przełożyć na inny dzień. Oto okazało się, że jej koleżanka dostała nowy wózek. Dziewczynkom całe zajęcia zajęło ustalanie, jakie napisy ma nanieść koleżanka na osłonie szprych wózka. Każda z nich umieszczała na osłonie radosne rysunki, wesołe napisy, które były swoistymi wizytówkami.

Dzieci nie traktowały swych wózków jak obcych sobie urządzeń. Wręcz przeciwnie - miały je za swoisty środek wyrazu własnych emocji. Wózek inwalidzki stał się dla nich poniekąd wizytówką, odpowiednikiem modnego stroju, nowego wzoru plecaka itp.

\section{X jak Xero}

Pacjentem miał być chłopiec z mózgowym porażeniem dziecięcym. Okazało się jednak, że jego dwaj bracia są także niepełnosprawni. Pierwszy z nich doznał urazu rdzenia kręgowego w okolicy szyjnej kręgosłupa po skoku do wody. Doszło do tego w jego osiemnaste urodziny. 
Drugi z braci chłopca także doznał urazu rdzenia kręgowego w okolicy szyjnej. Doszło do tego równo rok po pierwszym wypad$\mathrm{ku}, \mathrm{w}$ trakcie identycznego skoku do tej samej glinianki.

Tu chciałoby się zadać pytanie o potencjalną skuteczność programów profilaktycznych, w których przestrzega się przed brawurowymi skokami do wody, jeśli w gronie najbliższych bagatelizuje się doświadczenia.

\section{Y jak Youtube}

Nastolatek z podgórskiej wioski doznał urazu rdzenia kręgowego $\mathrm{w}$ okolicy piersiowej. $\mathrm{W}$ jego domu gościło liczne grono kolegów, kuzynów. Sprawiało to wrażenie nadzwyczajnej uroczystości, bowiem zwykle niepełnosprawni nastolatkowie nie mają licznego grona znajomych. Jego rodzice nie wykazywali jednak najmniejszego zdziwienia obecnością tak wielu rówieśników.

Okazało się, że choć chłopaka nie było stać na dobrze wyposażony komputer, to był on specjalistą $\mathrm{w}$ serwisowaniu tego rodzaju sprzętu. Naprawiał komputery innym, doradzał w sprawach oprogramowania.

Przed drugim spotkaniem chłopak otrzymał laptop, który był elementem terapii opartej na likwidowaniu jego ograniczeń komunikacyjnych. Władzom fundacji wspierającej nastolatka szczególnie zależało na tym, by był to najlepiej wyposażony $\mathrm{z}$ przenośnych komputerów dostępnych wówczas na rynku. Postanowiono rozwijać wysokie kompetencje chłopca, które być może są szansą na przyszłą aktywność zawodową.

W tle tego przykładu chciałoby się postawić pytanie badawcze o to, jak często instytucje świadczące pomoc dla osób niepełnosprawnych rozeznają realne potrzeby beneficjentów, a jak często jest to dystrybuowanie wystandaryzowanych świadczeń.

\section{Z jak Zawodowiec}

Ten pacjent po urazie rdzenia kręgowego stał się pracownikiem zakładu opieki zdrowotnej. Dołączył do grona kilku innych osób niepełnosprawnych $\mathrm{w}$ nim zatrudnionych. Wyróżniał się samodzielnością, niepowtarzalną techniką jazdy na wózku; trenował 
koszykówkę. Po kilku miesiącach zrezygnował jednak z pracy. Zdecydował się na wyjazd zagranicę. Klub koszykówki osób niepełnosprawnych zaproponował mu kontrakt zawodowy. Na meczach tej drużyny kibice płacili za bilety.

W trakcie rozgrywanych w Polsce finałów Mistrzostw Europy w Koszykówce na Wózkach trybuny, niestety, były puste. W jednej $\mathrm{z}$ drużyn grał mistrz olimpijski w rywalizacji zawodników pełnosprawnych, który doznał urazu rdzenia kręgowego.

Opisana sytuacja pozwala zadać pytanie o występowanie różnic kulturowych w podejściu do niepełnosprawności, w tym sportu osób niepełnosprawnych, ujawnianych wręcz w sąsiadujących państwach.

\section{Podsumowanie}

Syntetycznie przedstawione wybrane aspekty biografii rodzin osób niepełnosprawnych odzwierciedlają relatywnie rzadko analizowane empirycznie aspekty ich funkcjonowania. Niewykluczone, że niektóre $\mathrm{z}$ wyeksponowanych stanów mają jedynie status artefaktów. Zamieszczenie ich w relacji uzasadnia jednak cel eksploracji.

Celem prezentacji było ukazanie potencjalnych obszarów dalszych eksploracji, w tym między innymi zagadnień (w nawiasach podano symbol opisanego przypadku):

- wpływu uprawnień zawodowych jako czynnika integrującego losy osób niepełnosprawnych (A, Y) oraz dostępności w środowisku społecznym pozytywnych przykładów osób niepełnosprawnych, które odniosły sukces życiowy, w tym zawodowy $(B, Z)$,

- wtórnego wpływu rehabilitacji z jednej strony poszerzającej świadomość osoby niepełnosprawnej, a z drugiej strony stawiającej tym samym kolejne wyzwania i pola aktywności (E, Z),

- obiektywnej niedostępności świadczeń pomocowych dla osób, które w momencie urazu nie miały ubezpieczenia społecznego (R),

- reorientacji celów życiowych rodzin osób, które uległy urazom prowadzącym do niepełnosprawności znacznego stopnia (C, $\mathrm{R}, \mathrm{T})$, 
- zasadności stosowania form terapii poszerzających doznania osób niepełnosprawnych, zwłaszcza w wieku rozwojowym, w tym zabawy (D, W, Y),

- uwarunkowania skuteczności procesu terapeutycznego przez zasobność finansową rodzin (J, F, Y),

- regionalnych tradycji i uwarunkowań kulturowych troski o osoby niepełnosprawne oraz recepcji ich ograniczeń ruchowych $(G, K, Z)$,

- presji grupy rówieśniczej jako czynnika prowadzącego do niepełnosprawności młodocianych $(\mathrm{H})$, a także skłonności do ryzyka osób niepełnosprawnych (I),

- determinacji osób niepełnosprawnych w realizowaniu własnych strategii życiowych (A, K, L, M, T),

- ograniczonych możliwości przygotowania rodzin i terapeutów do mierzenia się $\mathrm{z}$ wyzwaniami niepełnosprawności $\mathrm{w}$ gronie najbliższych ( $($ ) oraz ograniczonej skuteczności programów profilaktycznych $(\mathrm{H}, \mathrm{X})$,

- nieadekwatnego postrzegania dysfunkcji przez samego niepełnosprawnego, jego rodzinę i otoczenie społeczne $(\mathrm{N}, \mathrm{K})$,

- niebezpieczeństwa urazów personelu medycznego $(\mathrm{O})$,

- borykania się osób niepełnosprawnych z procedurami administracyjnymi $(\mathrm{P}, \mathrm{T}, \mathrm{U})$,

- wpływu czynników klimatycznych (pogodowych) na częstość występowania urazów pewnego typu (S).

\section{Konkluzja}

Mnogość wyeksponowanych w podsumowaniu wątków i ich zróżnicowanie prowadzą do wniosku, że ich ewentualną eksplorację trudno byłoby ująć w pojedynczą procedurę badawczą. Z drugiej strony, dopiero kompleksowe, wieloaspektowe pogłębione dociekania mogą ujawnić istotne dla interpretacji złożoności zjawiska niepełnosprawności związki przyczynowo-skutkowe. 